\title{
Expectant parents' experiences of parental education within the antenatal health service
}

This article was published in the following Dove Press journal:

Psychology Research and Behavior Management

I5 December 201।

Number of times this article has been viewed

\author{
Ann Norling-Gustafsson ${ }^{1,2}$ \\ Katarina Skaghammar ${ }^{1,2}$ \\ Annsofie Adolfsson ${ }^{1,3}$ \\ 'School of life Sciences, University \\ of Skövde, Skövde, Sweden; ${ }^{2}$ Primary \\ Health, MVC, Karlsborg, Sweden; \\ ${ }^{3}$ Department of Obstetrics and \\ Gynecology, Skaraborg Hospital, \\ Skövde, Sweden
}

\begin{abstract}
Being an expectant parent is a life changing event and it is something that most people will experience in their lifetime. Many people who are parents for the first time will participate in parenting education. Most of the previous studies associated with parenting education focus on subjects such as birth outcome and breastfeeding. The purpose of this study is to focus on the less investigated aspect of the parents' experience of participating in parenting education with Maternal Healthcare Services (MVC). A qualitative, phenomenological, hermeneutical method was selected to be used to analyze our findings and we used the statements of twenty participants to accumulate enough material to develop it into twelve sub-themes and five themes. The results of this study show that these expectant parents had few or no expectations of the parenting education that they were going to participate in. Generally speaking the parents seemed to be satisfied with the program. They described their reasons for participating as a chance to get together with other people in similar circumstances and to share information and they found a midwife to be a trustworthy professional person to confirm the information that was available to them from other sources.
\end{abstract}

Keywords: parent education, parents' experiences, parents' expectations

\section{Introduction}

In the course of our work with Maternal Healthcare Services (MVC), midwives met with expectant parents to educate them about parenting. Midwives work within the range of goals that were developed by the National Board of Health and Welfare in 1979. ${ }^{1}$ A more recent concept of the National Board of Health and Welfare is that of the program evolving into support groups for prospective parents to develop them in their new role as parents. ${ }^{2}$ In this study, for simplicity's sake, we are using the original term "parent education" from the original goals of the National Board of Health and Welfare, even though the program has evolved into support groups. In the Swedish context no further studies were performed. With recent developments in society in the age of the internet there have been large changes in how information is being shared. Although expectant parents have so much information available to them via the internet in addition to the more traditional sources such as books, periodicals, relatives, and friends, parent education offered through the MVC is still relevant because parents need a single trustworthy source that they can rely upon to evaluate the plethora of information available. In addition, the MVC organization provides a network of social interaction that is supportive on a more personal basis than the internet can provide. 


\section{Need for parent training}

From a biological perspective, by definition, a man and a woman become parents when they have a child together. Realistically though, new parents need help in their new role of being a parent in terms of information, knowledge, advice and support. Often they are in need of assistance in order to feel the security and confidence that is needed to experience this new role in harmony with their lives. In the past twenty years the role of a parent has undergone a rather dramatic change. Parent education was originally seen as a means of preventing child abuse. The National Board of Health and Welfare decided in 1979 on a parenting education program that would target all parents around the time of the birth of their child. Modern society is characterized by increasing complexity, a breakdown in the nuclear family in many cases, and a faster rate of change than ever before witnessed, which is creating new conditions for parenting. ${ }^{2}$

\section{The goal of parent training}

According to the National Board on Parenting the overall goal is to strengthen parents by achieving three sub-goals. The first is to increase parents' general knowledge in terms of the physical, mental and social transformations that take place during pregnancy. This includes increasing their knowledge of child development and of the relationships between children and parents and other adults. Social relations and information about the social support available to families with children are other areas where the goal was to increase the parents' knowledge. The second objective is to create opportunities for parents to connect and socialize with other parents who are in similar situations, with the guidance of professional staff. The third goal is to help families become more aware of the impact of other social relations. Parents need to have the confidence to decide if they are in need of additional support themselves. ${ }^{2}$

\section{The aim of parenting training}

The primary objective of parent education is to promote the healthy, positive and natural aspects of giving birth and to assist parents to grow with their child. A family where parents and children are living in harmony together is one of the best quality of life situations people can aspire to. ${ }^{2}$ Parental education has an aspect of prevention as well. This is true particularly in first child situations and the parent education gives these new parents the opportunity to seek support and knowledge in a structured system designed to fulfill their needs.

\section{The midwife's role in parent training}

The relationship that is developed between the midwife and the pregnant woman is an important aspect of the woman having a positive experience during her pregnancy, childbirth and also during the early period after birth. The midwife must work to develop this trusting relationship. She should understand and believe in each woman's capacity to manage her child's birth and her inherent strength as a woman to

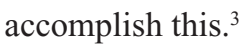

The midwife should have a pedagogical approach that will lead to reflective conversations and give the women and the families the opportunity to make new contacts. ${ }^{4}$ An American study concluded that the leaders of parent groups felt that the main purpose and accomplishment of parent groups was that parents gained the confidence to give birth to their babies and to become secure parents. ${ }^{5}$ Prospective parents want to be informed by a trustworthy and competent person and be given information that is applicable to everyone, accurate and reliable. ${ }^{6}$

\section{The couple's relationship and parenthood}

Becoming a parent, particularly for the first time, is a lifechanging event for both partners. There is a transition period that involves a change in identity where the parents are trying to find themselves in their new role as parents. The parents' attention is focused inward for a period of time in order for them to be able to find their identity in this new period of life and to help them to choose their direction and digest the content of their new and current phase of life. ${ }^{7}$ Those couples who are unhappy and seem to be under undue stress about their new situation and responsibilities, may experience a negative impact on their health or the health of the child. ${ }^{8}$

\section{Father's participation in parent training}

One study showed that expectant fathers wanted to support their partners, but often felt that they were unprepared when they attended the parent education with the expecting mothers. ${ }^{9}$ These men also felt more comfortable and productive in groups of men that had male group leaders. They also tended to have a better experience of the pregnancy and delivery. ${ }^{9}$ The fathers tended to feel that the women were more prepared for having children than they were. Men tended to feel that the pregnancy, parent education and childbirth were a "woman thing". This attitude could be a source of worry for them, concerning the delivery in particular. ${ }^{10}$ Another Swedish study found that parent education held a secondary role for the fathers and they often sought and found information from other sources. ${ }^{11}$ 


\section{Earlier research}

A Swedish study has found that $7 \%$ of first-time mothers and $81 \%$ of couples with more than one child did not participate in parenting education with the MVC. ${ }^{12}$ Hildingsson and Thomas ${ }^{13}$ showed in their research that parental education should be available to all prospective parents in order to provide them with the opportunity to build a social network. At the same time use of the internet is increasing as a source for information about pregnancy and child delivery, participation in parent education is decreasing. ${ }^{14} \mathrm{~A}$ study performed in the USA shows that participation in parent education has dropped from $70 \%$ to $56 \% .^{15}$

\section{Nursing theory perspective}

Swanson's nursing care theory can be applied by midwives and other health care providers, in different caring situations. A general application is accomplished in applying her nursing theory when it is divided into five categories for the midwife. The midwife must be competent in her knowledge, she should be emotionally present for the parents, she should try to meet each individual's needs, she should endeavor to be objective and she should give clear and comprehensive information in order to help the parents understand what will happen to them. ${ }^{16,17}$ The purpose of this study was to study the experiences of expectant parents with regard to their participation in parent education classes within the MVC.

\section{Method}

A qualitative approach was chosen to interpret the parents' perceptions of the parent education program. This approach is a systematic and subjective method that is used to describe life experiences by interpreting the themes and meaning in the described phenomena. The main objective in this approach is to understand the meaning of the narrative account using phenomenological hermeneutic structural analysis of the text. ${ }^{18}$

The qualitative approach is holistic, and was empirically developed at the Universities of Umea and Tromso. It is based on Ricoeur's philosophy and the following method steps: narrative stories, base understanding, structural analysis, comparison, and overall interpretation. The method is hermeneutic and is based on text interpretation and phenomenological method when seeking understanding and the meaning of words. ${ }^{19}$

Hermeneutic interpretation has several principles that revolve around constant interplay between the parts and the whole which is called the hermeneutic circle. From an uncertain and immediate understanding of some text that is interpreted as a whole, the reinterpretation and restructuring of the separate parts of the text create a new understanding of the text as a whole..$^{18,20,21}$

Phenomenology as a qualitative research approach tries to capture and describe the living world experience. When individuals experience something, they form an opinion about the meaning and content of that experience. The characteristic feature of phenomenology is to capture the experience of a phenomenon by describing the experience as it manifests itself in the information, without interpreting it. Phenomenology is not interested in hidden or subliminal messages. ${ }^{22}$

Pre-understanding means that reality is not only perceived by the senses. We have been socialized in our own community so that we perceive reality in a way consistent with the culture of the society. By constantly experiencing new situations we are always revising our pre-understanding. ${ }^{23}$

Our life experiences are based on the living world and our relationship with it. A living world perspective involves describing the world from a person's everyday world and everyday life. The living world is the reality that we live in and experience every day, and we tend to take it for granted. It is through the living world that we experience love, hate, work, play, and thought. In the living world we are looking for the meaning of life through its contents and our perceptions. The objective of the living world approach is to explore and understand the world without distorting it. In this approach it is essential to always be open, receptive and responsive to the phenomenon being studied. ${ }^{24-26}$

\section{Selection of participants}

The participants in this study were twenty men and women who were expecting their first child. They were all Swedish speaking, literate and had completed parent education during a pregnancy at some time between August 2008 and January 2009. In August, midwives invited 56 potential participants from three different midwife clinics and only two responded with a written submission of the two question survey. Between October 2008 and January 2009 another 24 potential participants were recruited by the authors of the study from the three clinics and of these 18 responded with written responses. Each of the three locations conducted from between five to eight sessions per parent group which lasted about 2 hours each Each parent group was made up of four to ten couples. The content of the training was consistent at all of the clinics and included information about childbirth, pain management, breastfeeding, bonding and parenting. Staff members from the Child Healthcare Services, the family center, family 
counseling and the social insurance agency were invited to participate with the groups to different degrees. Education of fathers was a subject that was covered at the meetings. All of the clinics were tied to the family healthcare system.

\section{Data collection}

The data for this study was collected between August 2008 and January 2009. The managers of the respective clinics were asked in writing for permission to collect data. The midwives at clinics received written information about the purpose of the study and about how it would be conducted. The information sheet was distributed by the midwife at the clinic to those parents who had participated in the parent education program. The twenty parents who chose to participate in the study were asked to write down their recollections of their experiences and answer the questions: "What expectations did you have for the parent education?" and "Did the parent education live up to your expectations?". The participants wrote down their recollections and forwarded their stories and the answers to the questionnaire to the authors of the study to whom they had given their written consent to participate. The responses were handwritten and ranged in length from one-half page to three pages long.

\section{Data analysis}

To analyze something means to separate it into parts. Analyzing a narrative involves fragmenting the whole into individual elements such as sections, phrases and words. ${ }^{18}$ The authors chose to analyze the material on the basis of the phenomenological hermeneutical method of Lindseth and Norberg. ${ }^{19}$ This analysis method includes three steps: base understanding, a structural analysis and the interpreted whole. The base understanding involves reading the text several times to get a feeling and an understanding of the text as a whole. In this phase of the analysis it is important to remain open and impressionable in order to see what the text has to say. From this, the essence of the text emerges. The structural analysis is the methodological part of the process. It is important during this part of the process to remain as objective as possible with the text. The text is first divided into meaning-bearing units. These units may consist of a word, a sentence, several sentences or a paragraph. The meaning-bearing units are read and reflected upon relative to the base understanding of the text and in this manner the text is condensed. Condensing the text into units and expressing it in everyday language is the essential function of the meaning-bearing units. These condensed text units are read and reflected upon in order to see similarities and differences in the different stories. Then by comparing the similarities in the texts, sub-themes emerge. These sub-themes are then combined to create the different themes in the texts. The themes are then compared and evaluated against the base understanding of the texts to see if they make sense and comply with the rationale. If the themes do not comply, the process must be repeated. The text in this way is connected to a unit that is based on the purpose of the study, the base understanding, and is the result of the structural analysis (see Table 1) and the author's prior understanding. This result of the analysis is called the interpreted whole. ${ }^{19}$

\section{Results}

The impression of the first understanding of the texts as a whole (base understanding) is about the parents' experience of "expectations met" and "expectations not met" when they participate in parent education. In a significant way, it is about "expectations met" even if the parents have not always expressed any expectations for the parent education program or if they have expressed having few expectations. The general perception of the parent education is that it is worthwhile, the parents seem to be satisfied and they would recommend that all parents participate in the program. The significance of their experience having met their expectations is accomplished by giving them relevant information that they believe they need from a competent, professional person. In addition, they have the opportunity to meet other parents who are in similar circumstances to their own. The text of the parents expresses a strong need to create a social network with other parents in order to share and compare experiences and knowledge about the process of giving birth and the role associated with becoming a parent. Their experience when their expectations were not met generally referred to what they felt to be a lack of relevant information and a lack of satisfaction with some aspect of the presentation of the information.

Based on the assumptions made in the base understanding of the text, a structural analysis of the text was made. The structural analysis resulted in twelve sub-themes and the five themes. The results are presented based on these five themes (Table 2).

\section{Discussion of results To feel socially connected}

Pregnancy is a pivotal process in the life of a person that presents an opportunity for meaningful personal growth and for the forging of relationships with others. A man and the woman change from being just a couple to being a family. It creates a new group dynamic and identity that in turn creates the need for a new social network. The text of 
Table I Example of the process of the structural analysis

\begin{tabular}{|c|c|c|c|}
\hline Meaning-bearing units & Condensation & Sub-themes & Theme \\
\hline $\begin{array}{l}\text { Thought that it would be interesting to meet } \\
\text { other parents and knowing also that they are } \\
\text { getting closer to delivering the baby and to } \\
\text { be the parent that they desired to be. }\end{array}$ & $\begin{array}{l}\text { Interesting to meet other expecting } \\
\text { parents, knowing that the delivery is } \\
\text { getting closer, and the urge to become } \\
\text { a parent. }\end{array}$ & $\begin{array}{l}\text { To meet others in similar } \\
\text { situations. }\end{array}$ & $\begin{array}{l}\text { To feel socially } \\
\text { connected. }\end{array}$ \\
\hline $\begin{array}{l}\text { It was nice to meet and talk with others in } \\
\text { the same situation as me... to hear what } \\
\text { they had on their mind and things like that }\end{array}$ & $\begin{array}{l}\text { It was nice to meet with other } \\
\text { expectant parents to talk and discuss. }\end{array}$ & To exchange experiences. & \\
\hline $\begin{array}{l}\text { I expected a review of the delivery itself } \\
\text { and we got it and even saw an old movie. } \\
\text { We even talked about different pain relief. }\end{array}$ & $\begin{array}{l}\text { I expected a review of the delivery } \\
\text { and pain relief. }\end{array}$ & To obtain information. & To get knowledge. \\
\hline $\begin{array}{l}\text { The group had a good size and composition. } \\
\text { There was one girl who was really good, } \\
\text { she had a number of children and because } \\
\text { she was alone she was extra important } \\
\text { and she got a lot of questions. }\end{array}$ & $\begin{array}{l}\text { Good size and composition of the group, } \\
\text { good with multiple birth mother, } \\
\text { she was meaningful and got a lot } \\
\text { of questions. }\end{array}$ & Good with experience & \\
\hline $\begin{array}{l}\text { However the midwife did give information } \\
\text { about some things that I had not thought of, } \\
\text { and this shows that there must be some sort } \\
\text { of standard of what every parent should know. } \\
\text { Breastfeeding, bonding, milk supply and so on. }\end{array}$ & $\begin{array}{l}\text { The midwife gave information about } \\
\text { things that I had not thought of so this } \\
\text { indicates there is a need for standardized } \\
\text { information. }\end{array}$ & $\begin{array}{l}\text { A wish to get information } \\
\text { from the midwife. }\end{array}$ & The role of the midwife. \\
\hline $\begin{array}{l}\text { It seemed to me that the midwife informed } \\
\text { us in a relevant, fun and factual manner } \\
\text { without lecturing, which I think is important. }\end{array}$ & $\begin{array}{l}\text { The midwife gave relevant information } \\
\text { in a nice manner and that is important. }\end{array}$ & Competent midwife. & \\
\hline
\end{tabular}

the parents describes the desire to meet other parents who are in the same situation as themselves. Current friends and acquaintances may not be experiencing the same phase of life. This means that parents no longer feel they have as much in common with their "old network" during this period. The parent education program also fills a need for those who do not have their own networks in place; for example, expectant parents who are new in their communities and families who do not have the local support of their parents or relatives.

"It was fun to meet other people in the same situation. We were relatively new arrivals in town and it gave us a chance to meet people."

Table 2 Sub-themes and themes

\begin{tabular}{|c|c|}
\hline Sub-themes & Themes \\
\hline To meet others in a similar situation & To feel socially \\
\hline To collaborate with these others & connected \\
\hline \multicolumn{2}{|l|}{ Changing experience } \\
\hline To get information & Receiving \\
\hline Benefit from the experience of others & knowledge \\
\hline Dare to ask & $\begin{array}{l}\text { Permissive } \\
\text { atmosphere }\end{array}$ \\
\hline Insufficient information & Perceived \\
\hline Not enough meetings & shortcomings \\
\hline \multicolumn{2}{|l|}{ Unsatisfied with the information } \\
\hline \multicolumn{2}{|l|}{ Experienced unsuccessful contact with the group } \\
\hline Good and competent midwife & The midwife's role \\
\hline A desire to get information from the midwife & \\
\hline
\end{tabular}

The parent education program is an excellent forum in which to share experiences and to discuss pregnancy, childbirth, parenting potential and other related issues. Parents get the opportunity to ask questions and to share their common concerns. It provides them with an opportunity to talk about the changes that they experience physically, mentally and emotionally during the pregnancy and also about those impending changes that they will face as new parents.

"It was nice to meet and talk with others in the same situation ... to hear what they had on their minds and such."

"Use the group to see how others worked through and solved different problems."

The social interaction is greatly appreciated and is one of the most important reasons cited that parents choose to participate in the program. The opportunity to continue to maintain contact and to be able to get together after everyone in the group had had their babies demonstrated the significance of the group's importance to the parents. The parents consider the acquisition of a new or increased social network to be very valuable.

"Expectations ... it was mainly to meet others in similar situations, to have a larger network of contacts ... people who you can even hang out with ... people with common experiences and interests." 
"I look forward to seeing the others in the group after they give birth ... it is really positive to both of us to have this group and the related activities."

\section{Receiving knowledge}

Pregnancy is such an important transitional period in a person's life and such a significant event that most people only go through it once or at most several times in the course of their lifetime. Because of the significance of this, it is important to know as much as possible about childbirth and the period afterwards. The statements demonstrate that the parents are highly motivated to get information and to discuss the important issues that are associated with parenthood. Generally speaking, they do not feel prepared without the knowledge that they acquire through the parent education. According to the parents, the structure and content of the program is adequate enough for them to think that it is a rewarding experience. The participation of a range of different staff who were associated with the parent education program was appreciated and it gave the parents an opportunity to ask questions of different people with various qualifications. The parents felt that the program provided quality information about the subjects of pregnancy and birth that they were not aware of before attending the training. This made a strong impression on them. Their experience was that it was difficult to anticipate the things that they should know and that they needed to know before the baby arrived in their lives.

"The organization and setup of the training was impressive. There were different personnel there to address different concerns ... people from the social services and family law for example were there. I wasn't really expecting that."

"I thought that the program was more comprehensive than I expected."

It is a positive feeling to able to share the experiences of other parents who already have had children before the training began. This was an opportunity to acquire knowledge informally from a person who can be seen as a source and a model that the parents could identify with. This knowledge sharing adds another dimension to the program. Parents are very aware and in some ways hyper-sensitive to their experiences with their babies.

"We had in our group both first time parents and couples that have had children already. It was truly a rewarding experience."

\section{Perceived shortcomings}

There were some parents who expressed some disappointment with some aspects of the program. These parents responded that they would have liked to have had some more information or some alternative information than that provided in the program. Given the perceived shortcomings, the parents were relatively happy and satisfied on the whole with the parent education. There are parents who did not visit the maternity ward. They did not think the homepage on the Internet website with pictures was as informative as a visit. Parents want to see the actual layout of the ward itself and they want to meet the staff and experience the environment of the maternity ward firsthand. There were participants who thought that the number of meetings was too few, which indicates a need for more time together as a group. There are parents who want very detailed information on subjects such as childbirth, post childbirth and breastfeeding, to satisfy their need for a sense of control. They may experience a feeling of being thrown into the unknown when they do not feel they are prepared for everything that will be thrown their way in their new role as parents. They feel a lack of control.

I was disappointed that we would not take up on relaxation technique with the coordination of deep breathing and labor contractions, it was only five times, and we (me and my boyfriend) looked forward to quiet our concerns through visits to the delivery ward. Going on the website is not the same.

But I never understood the whole purpose of the program. We got there, got some information, had refreshments, saw a movie and went home. When I got home I asked myself... what have I learned? Keep your breasts warm, talk to your child, communicate with your partner and share the responsibility. But what about vaccinations, how can you avoid the tearing during childbirth, what can I do to make breastfeeding work if it is not working, what feelings will I experience after the birth... there were some unanswered questions.

In some groups the participants did not have good contact with each other and therefore the discussions seemed to be fruitless and were "running out of steam". In some groups there are participants who are quiet, passive and unengaged. The parents may also have different needs to discuss and listen. These factors can lead to a lack of chemistry and poor group dynamics.

It's all well and good with the parent education, it is a good idea and a good forum to meet others and discuss difficulties... potential problems and issues. But if the group is quiet, uninterested or do not have the same needs... the expectations of the group is low.

\section{Permissive atmosphere}

The experience of the parents regarding the mood of the group is that it becomes more and more relaxed each time 
they meet. This gives the participants a sense of security which makes it easier to dare to ask questions and to openly air their issues and concerns in the presence of the group. Parents do not feel that they are unique or so different from the other participants when they hear the others' questions and thoughts that are often similar in character. This gives a comfortable feeling and creates an increasingly tolerant atmosphere within the group.

"The mood after the first meeting becomes more relaxed ... because everyone gets over their initial embarrassment ... then you can ask the 'stupid' questions ... which really aren't that stupid after all. There were others that had the same questions."

\section{Midwife's role}

According to the statements, the midwife has a significant role to play with the parents. Parents want to obtain information that they feel they need from a professionally qualified person. The parents feel that the information that they read in the available literature and learn about through the media and from other parents before the parent education program is insufficient. Information from the midwife is not always something new for the parents but it gives them a sense of confirmation that what they already suspected to be true, is true. Participation in parent education is reassuring to prospective parents. The midwife can make information more comprehensible which can help the parents to develop a deeper understanding. The parents want to discuss the facts they already have in their possession with the midwife and it demonstrates that they develop more confidence in the professional person as a competent reliable source. Parents think that it is important that the group leader has an educational and open approach that leads to reflective discussion among participants and provides them with the ability to make new contacts. The statements also indicate that the midwife should be responsive to parents' wishes. The parents feel the "standard information" from the midwife is positive and secure because they could not have possibly thought of everything in connection with parenting. The statements describe there is some security in knowing that there is some kind of standard information on parenting, that is provided by the society through the midwife.

"NN (the midwife) is really competent, low keyed, educational, and responsive to our individual needs."

"I thought that the midwife informed us in a relevant, fun and factual manner without the sense that we were being lectured to ... which I think is important."
"Get answers from someone who knows about the situation."

"We had already read the information in the books before ... so it was not exactly news to us ... but it is good to hear how others think and reason. Some of the news was actually news to us ... we got some clarification of questions from literature and by listening to other people's stories of having babies."

\section{Summary of discussion of results}

The results from the analysis of the statements reveal that the parents are generally satisfied and have had a positive experience from the parent education program. The parents had few or no expectations at all prior to the program, but they did want to meet with other expectant parents and exchange information. The program enabled expectant parents to form a social network with others in their situation. Even though many parents did a lot of research about pregnancy, childbirth, and parenting before the parent education program, they wanted to participate in the program in order to better prepare themselves. Parents expressed a need to have their knowledge and findings validated by the midwife which shows that she plays a significant role with the parents in the program. The midwife provides the parents with a sense of security.

\section{Further discussion}

Even though on the whole, the results of the study show that the men and women who participated were generally satisfied with the program, there were still some expectations that needed to be resolved. The MVC should systematically develop, investigate, document and summarize the findings from the reports to make it possible to use these results as a basis for further planning and decisions. The challenge is to develop a program that responds to the individual needs of parents in order to enhance their confidence in their own ability to be parents. ${ }^{4}$ In order for midwives to grow comfortable as group leaders, it is important that they get the opportunity for further training in how to develop the program in terms of both the pedagogical aspects and the content. Based on the goals of the State Health Authorities, ${ }^{1}$ each midwife develops a parent education program according to her own interpretation and in her own way. ${ }^{31}$ Based on these findings, it is important to develop a standard basis of information that does not overemphasize medical information, but instead places greater emphasis on more relationshiporiented issues and psychosocial problems. ${ }^{2,31}$

The results of this study can be analyzed according to Swanson's Caring Theory ${ }^{16,17}$ with respect to the different caring categories. The first caring category in Swanson's theory is 
for the midwife to be knowledgeable and to be competent as an information broker. She assumes the role of the authority and her duty is to confirm or reject the information that the parents have accumulated before participating in the training. The midwife is well aware that becoming a parent has the potential to turn into a life crisis for couples and she has the opportunity to not only discuss the potential difficulties that lie in store for the expectant parents, but she can be proactive in identifying those couples that are having issues with their parenting roles and refer them to the proper channels where they may find additional support.

Swanson's second category in her caring theory is Being Present, which means that the midwife is a professional person with a pedagogical approach. She confirms in the parents their ability to be competent and she is sensitive and responsive to their needs, which is conducive to reflective conversation. It is the parents' questions and concerns that serve as the starting point in the discussions between the midwife and the parents. The relationship between the midwife and the parents is based on the midwife's ability to provide support based on individual needs.

The third category in her caring theory is Doing For, which assumes that the parents will normally make their own decisions about what their needs are, but in this new situation they find themselves in need of the midwife's expertise. The midwife provides the information that the parents are in need of and she supplements and confirms those skills that the parents already possess. The parents can find some comfort in knowing they have in their possession all of the standard information that the parent education program provides. The midwife can confirm for the parents what they already have the capability to do, but are not yet aware of.

The fourth category of the caring theory is Enabling. This means that the midwife has the ability and skill to strengthen the expecting parents' security and their confidence in themselves and their ability to do well in their new role as parents. An educational approach accompanied by attentive listening and the answering and confirmation of the parents' questions strengthens them in their parenting role. In the training sessions the woman is taught to trust in the natural ability of her body to accomplish the task of delivering the baby, and couples are instructed how to support each other during the delivery. Couples expressed in their reports that they were very interested in creating a social network with other parents and expecting parents. The parent groups were found to be very effective at facilitating the creation of these networks.

The final category in Swanson's theory is Maintaining Belief, which indicates that with the support of the parent education, the parents develop confidence in their own capacity. The midwives trust in the parents' innate ability to bear their children and to be good and competent parents. A large part of their responsibility is to get the parents to understand this and believe in themselves. Parents get a unique opportunity to form new contacts with other people in similar situations and it is possible to maintain these contacts as they adjust to their new role.

\section{Limitation}

The results in this paper represent the written answers to the study questions by twenty men and women. A possible limitation of this study is the limited number of respondents.

\section{Further studies}

There is a need for new studies to develop educational methods to be used in the parent education program. This could be potentially helpful for the midwives in their working relationship with the parents who are participating in the education program. One interesting aspect deserving of further study is why couples who already have children are more reluctant to participate in the program. How can this particular group be encouraged to increase their participation? Another potential question for further study is how parents themselves can be made to be more responsible for the program's contents and methods. Where is the line where the midwife's responsibility ends and the responsibility of the parents begins? How would midwives feel about serving as a consultant to the program instead of being the driver of the program?

The results of our study included men and women in the same set of responses. Is it possible that there are differences between the sexes in their feelings that this study did not reflect? It would be interesting to investigate whether there are any differences between men and women with respect to their expectations and their experiences of parenting.

\section{Conclusion}

A unique aspect of this study is that the results indicate how parents felt about the parenting training conducted by the MVC before they became parents. The expecting parents were generally satisfied with the parent training and only expressed the need for some minor changes in the program. This demonstrates to the midwives that are conducting the training, that the tasks and objectives that they try to accomplish in the interests of the parents are well received by the parents-to-be. The midwife cannot be replaced with mere information from various sources such as the internet, books, magazines or other forms of media. It is a requirement of the parents who participated in this study, that there is a competent and professional human being responsible for dispensing the necessary information to them during the course of the training. According to two reports ${ }^{4,31}$ there is a need 
for a national plan to develop parenting skills and knowledge and to also encourage parents to take more responsibility for the content and direction of the parent groups. Such a plan could conceivably help to standardize parent education and provide an abundance of feedback with regard to the benefits of the training. If the parents were to take a greater responsibility for the parenting groups it may be more effective in meeting their needs than the current top-down perspective where the MVC is the organization inviting the parents and specifying the curriculum. Parents tend to be more on top of developments in society and are therefore aware of what they need from parent training in order to address and adjust to current trends in parenting.

\section{Disclosure}

The authors report no conflicts of interest in this work.

\section{References}

1. Socialdepartementet. Report from the Child Care Group. First around the child's birth [Föräldrautbildning. Betänkande från barnomsorgsgruppen. 1. Kring barnets födelse], Stockholm: Socialdepartementet; SOU 1978:5. [Swedish].

2. Socialdepartementet. Report of the investigation for parent education [Stöd i föräldraskapet. Betänkande av utredningen om föräldrautbildning]. Stockholm: Socialdepartementet; SOU 1997:161. [Swedish].

3. Lundgren I, Berg M. Central concepts in the midwife-woman relationship. Scand J Caring Sci. 2007;21(2):220-228.

4. Interest Group for Maternity Care in the Swedish Association for Obstetrics and Gynecology, and Coordination Midwives in Swedish Midwives Association in collaboration with Maternal Health Psychologists' Association [Intressegruppen för mödrahälsovård inom Svenska föreningen för obstetrik och gynekologi, \& Samordningsbarnmorskorna inom Svenska barnmorskeförbundet i samarbete med mödrahälsovårdspsykologernas förening] Maternal health, sexual and reproductive health, Report 59 [Rapport 59. Mödrahälsovård, Sexuell och Reproduktiv Hälsa]. 2008. [Swedish].

5. Nolan ML, Hicks C. Aims, processes and problems of antenatal education as identified by three groups of childbirth teachers. Midwifery. 1997;13(4):179-188.

6. Svensson J, Barclay L, Cooke M. The concerns and interest of expectant and new parents: Assessing learning needs. J Perinatal Educ. 2006; 15(4):18-27.

7. Brodén M. Pregnancy possibilities: a time when relationships are created and developed [Graviditetens möjligheter: en tid då relationer skapas och utvecklas]. Stockholm: Natur och Kultur; 2004. [Swedish].

8. Polomeno V. Marriage in the transition to parenthood: how can perinatal education help? Or can it? Int J Childbirth Educ. 2007;22(2):21-29.

9. Wöckel A, Schäfer E, Beggel A, Abou-Dakn M. Getting ready for birth: impending fatherhood. Br J Midwifery. 2007;15(6):344-338.

10. Hallgren A, Kihlgren M, Norberg A, Forslin L. Women's perceptions of childbirth and childbirth education before and after education and birth. Midwifery. 1995;11(3):130-137.

Psychology Research and Behavior Management

\section{Publish your work in this journal}

Psychology Research and Behavior Management is an international, peerreviewed, open access journal focusing on the science of psychology and its application in behavior management to develop improved outcomes in the clinical, educational, sports and business arenas. Specific topics covered include: Neuroscience, memory \& decision making; Behavior
11. Premberg A, Lundgren I. Fathers' experiences of childbirth education. $J$ Perinatal Educ. 2006;15:21-28.

12. Fabian H, Rådestad I, Waldenström U. Childbirth and parenthood education classes in Sweden: Women's opinion and possible outcomes. Acta Obst Gynecol Scand. 2005;84(5):436-443.

13. Hildingsson I, Thomas J. Woman's perspectives on maternity services in Sweden: Processes, problems and solutions. J Midwifery Womens Health. 2007;52(2):126-133.

14. Romanao AM. A changing landscape: implications of pregnant women's internet use for childbirth educators. J Perinatal Educ. 2007; 16(4):18-24

15. De Vries CA, De Vries RG. Childbirth education in the 21st century: an immodest proposal. J Perinat Educ. 2007;16(4):38-48.

16. Swanson MK. Empirical development of a middle range theory of caring. Nurs Research. 1991;40(3):161-166.

17. Jansson C, Adolfsson A. Application of Swanson's Middle Range Caring Theory in Sweden after miscarriage. Inter J Clin Med. 2011;2(2):102-109.

18. Kvale S. The Qualitative Research Interview. Lund: Studentlitteratur; 2007.

19. Lindseth A, Norberg A. A phenomenological hermeneutical method for researching lived experience. Scand J Caring Sci. 2004;18(2):145-153.

20. Blamey K, Ricoeur P, Thompson JB. From Text to Action. Evanston: Northwestern University Press; 1991.

21. Bengtsson J. With the lifeworld as a basis [Med livsvärlden som grund]. Lund: Studentlitteratur; 2005. [Swedish].

22. Giorgi A. The theory, practice, and evaluation of the phenomenological method as a qualitative research procedure. J Phenom Psychol. 1997; 28(2):235-261.

23. Malterud K. Qualitative methods in medical research [Kvalitativa metoder i medicinsk forskning]. Lund: Litteratur for students; 1998. [Swedish.]

24. Schott J. Parent education: preparing for life after birth. Pract Midwife. 2000;5(6):37-39.

25. Dahlberg K, Segesten K, Nyström M, Suserud B-O, Fagerberg I. To understand health research. [Att förstå vårdvetenskap]. 2 Lund: Studentlitteratur; 2003. [Swedish.]

26. Dahlberg K, Drew N. A lifeworld paradigm for nursing research. J Holistic Nurs. 1997;15(3):303-317.

27. Tighe MS. An exploration of the attitudes of attenders and non-attenders towards atenatal education. Midwifery. 2010;26(3):294-303.

28. Berg M, Lundgren I. To support and strengthen. Caring for childbearing [Att stödja och stärka. Vårdandet vid barnafödande]. Lund: Studentlitteratur; 2004. [Swedish].

29. Hallgren A, Kihlgren M, Norberg A. A descriptive study of childbirth preparation provided by midwives in Sweden. Midwifwery. 1994;10(4): 215-224.

30. Fabian H, Rådestad I, Waldenström U. Characteristics of Swedish women who do not attend childbirth and parenthood education classes during pregnancy. Midwifery. 2004;20(3):226-235.

31. Distriktssköterskeföreningen i Sverige, Riksföreningen för barnsjuksköterskor, Mödra- och barnhälsovårdspsykologernas yrkesförening \& Svenska barnläkarföreningen. Early parenting - an in-depth description and analysis of early parental support in maternal and child health care [Tidigt föräldrastöd - en fördjupad beskrivning och analys av det tidiga föräldrastödet inom mödra- och barnhälsovården]. 2007. Available from: http://www.distriktsskoterska.se/dokument.php?cat=1\&id=1. Accessed December 2, 2011. [Swedish].

\section{Dovepress}

modification \& management; Clinical applications; Business \& sports performance management; Social and developmental studies; Animal studies. The manuscript management system is completely online and includes a quick and fair peer-review system. Visit http://www.dovepress. com/testimonials.php to read real quotes from published authors. 